\title{
Arsenic trioxide-induced apoptosis is independent of stress-responsive signaling pathways but sensitive to inhibition of inducible nitric oxide synthase in HepG2 cells
}

\author{
Shin-Hae Kang ${ }^{2}$, Ji-Hoon Song ${ }^{2}$, \\ Hee-Kyoung Kang ${ }^{1}$, Ji-Hoon Kang ${ }^{1}$, \\ Se-Jae Kim ${ }^{2}$, Hyun-Wook Kang ${ }^{1}$, \\ Young-Ki Lee ${ }^{1}$ and Deok-Bae Park ${ }^{1,3}$ \\ ${ }^{1}$ Department of Medicine, College of Medicine and \\ ${ }^{2}$ Department of Life Science, College of Natural Science \\ Cheju National University, Ara-1, Jeju 690-756, Korea \\ ${ }^{3}$ Corresponding author: Tel, 82-64-754-3827; \\ Fax, 82-64-725-2593; E-mail, parkdb@cheju.ac.kr
}

Accepted 12 March 2003

Abbreviations: APL, acute promyelocytic leukemia; ATO, arsenic trioxide; DPI, diphenyleneiodonium; ERK, extracellular signal-regulated protein kinase; ETU, 2-ethyl-2-thiourea; GED, guanidinoethyldisulfide dihydrochloride; JNK, c-jun $\mathrm{NH}_{2}$-terminal kinase; MAPK, mitogen-activated protein kinase; NAC, $\mathrm{N}$-acetylcysteine; ROS, reactive oxygen species

\begin{abstract}
Arsenic trioxide $\left(\mathrm{As}_{2} \mathrm{O}_{3}\right)$ has been found to be remarkably effective in the treatment of patients with acute promyelocytic leukemia (APL). Although evidences for the proapoptotic activity of $\mathrm{As}_{2} \mathrm{O}_{3}$ have been suggested in leukemic and other solid cancer cells, the nature of intracellular mechanisms is far from clear. In the present study, we investigated $\mathrm{As}_{2} \mathrm{O}_{3}$ affect on the stress-responsive signaling pathways and pretreatment with antioxidants using HepG2 cells. When treated with micromolar concentrations of $\mathrm{As}_{2} \mathrm{O}_{3}, \mathrm{HepG} 2$ cells became highly apoptotic paralleled with activation of caspase-3 and members of mitogen-activated protein kinases (MAPKs) including extracellular signal-regulated kinase (ERK) and c-jun $\mathrm{NH}_{2}$-terminal kinase (JNK) but not p38 MAP kinase. However, inhibition of each kinase activity failed to inhibit apoptosis by $\mathrm{As}_{2} \mathrm{O}_{3}$. Addition of $\mathrm{n}$-acetyl cysteine (NAC) or diphenyleneiodonium (DPI) effectively protected cells from apoptosis and significantly lowered $\mathrm{As}_{2} \mathrm{O}_{3}$-induced activation of caspase-3. However, neither NAC nor DPI was able to effect ERK
\end{abstract}

or JNK activation induced by $\mathrm{As}_{2} \mathrm{O}_{3}$. Guanidinoethyldisulfide dihydrochloride (GED) and 2-ethyl2-thiopseudourea (ETU), known inhibitors of the inducible nitric oxide synthase (iNOS), also suppressed the apoptotic activity of $\mathrm{As}_{2} \mathrm{O}_{3}$. These results suggest that $\mathrm{As}_{2} \mathrm{O}_{3}$ induces caspase-mediated apoptosis involving a mechanism generating oxidative stress. However, activation of some stressresponsive signaling pathways by $\mathrm{As}_{2} \mathrm{O}_{3}$ may not be the major determinant in the course of apoptotic processes.

Keywords: antioxidant; apoptosis; arsenicals; extracellular signal-regulated kinase; mitogen-activated protein kinase; nitric oxide synthase

\section{Introduction}

Arsenic trioxide $\left(\mathrm{As}_{2} \mathrm{O}_{3}\right)$ has been used as a therapeutic agent for centuries to treat several diseases like as anaemia, dyspepsia and some tumors (Huang et al., 1995). Recently, $\mathrm{As}_{2} \mathrm{O}_{3}$ was found to be a very potent anti leukemic reagent, especially against acute promyelocytic leukemia (APL) (Shen et al., 1997) by inducing apoptosis (Soignet el al., 1998). $\mathrm{As}_{2} \mathrm{O}_{3}$ induced apoptosis in different myeloid leukemia cell lines such as HL60, U937 and KG-1 (Wang et al., 1998). Although the precise mechanism of $\mathrm{As}_{2} \mathrm{O}_{3}$ action is still unclear, a variety of in vitro studies suggest that several mechanisms may be involved in the remission of leukemic cancer cells. Studies of the APL cell line NB4 and other myeloid leukemia cell lines treated with $\mathrm{As}_{2} \mathrm{O}_{3}$ showed down-regulation of the $\mathrm{Bcl}-2$ protein (Thomas et al., 2000) and activation of caspases (Akao et al., 1998). Number of reports on arsenic compounds treated different malignant cell lines indicate proapoptotic actions may dependent on p53. In gastric cancer cells and in MBC-1, a B-cell lymphoma line, $\mathrm{As}_{2} \mathrm{O}_{3}$ exposure causes up-regulation of p53 gene expression, resulting in caspase activation leading to apoptosis (Shen et al., 2000; Jiang et al., 2001). In human fibroblasts, arsenite causes breakage of DNA strand, which leads to accumulation and phosphorylation of p53 (Yih and Lee, 2000). Roles of the cell cycle inhibitor p2 $7^{\mathrm{KIP} 1}$ and Cip1/p21 
in $\mathrm{As}_{2} \mathrm{O}_{3}$ induced apoptosis also have been suggested (Ishitsuka et al., 2000). On the other hand, evidences from different model systems have suggested the ability of arsenic compounds to affect signaling molecules, especially, members of mitogen-activated protein kinases (MAPKs). c-Jun $\mathrm{NH}_{2}$-ternimal kinase (JNK) as well as p38, not extrasignal-regulated protein kinase (ERK), are activated by arsenic compounds (Cavigelli et al., 1996; Porter et al., 1999) whereas ERK is activated by arsenic in bronchial epithelial cells (Wu et al., 1999). Barchowsky et al. (1999) observed activations of ERK and p38 in arsenite- induced apoptosis in primary vascular cells. Chronic exposure to $\mathrm{As}_{2} \mathrm{O}_{3}$ has resulted in numerous pathogenesis such as lung and skin cancers, noncancerous skin lesions, peripheral nerve effects, and cardiovascular changes (Snow, 1992).

Homeostasis of natural oxidation and reduction equilibrium within cells is crucial for maintaining cellular viability. Arsenic compounds are known to imbalance such equilibrium, thereby generating oxidative stress resulting in sensitizing a number of signaling molecules including AP-1, NF- $\kappa \mathrm{B}, I_{\kappa} \mathrm{B}, \mathrm{p} 53, \mathrm{p} 21^{\text {ras }}$ (Simeonova and Luster, 2000). The cellular effects of complex redox reactions with endogenous oxidants and antioxidant systems in response to arsenic chemicals have been reported (Miller et al., 2002). However, it is far from clear to comprehend all activities of different signaling molecules affected by arsenic chemicals in different cellular systems. Thus, it is important to determine the sensitivity of different tumors against $\mathrm{As}_{2} \mathrm{O}_{3}$ and action mechanism of its anti-tumor activity. In the present study, we examined whether $\mathrm{As}_{2} \mathrm{O}_{3}$ can induce apoptosis in HepG2 cells and by which stimulations of stress-responsive signaling proteins are participating. Moreover, the effects of different antioxidant systems against the apoptotic activity of $\mathrm{As}_{2} \mathrm{O}_{3}$ were also investigated.

\section{Materials and Methods}

\section{Materials}

PD98059, SB202190, the fluorogenic caspase-3 substrate, Ac-DEVD-AMC, and the caspase inhibitor, zDEVD-fmk, propidium iodide, guanidinoethyldisulfide dihydrochloride (GED), 2-ethyl-2-thiopseudourea (ETU) were obtained from Calbiochem (La Jolla, CA). Arsenic trioxide $\left(\mathrm{As}_{2} \mathrm{O}_{3}\right)$, wortmannin, Dulbecco's modified Eagle's medium (DMEM), trypsin-EDTA solution, n-acetylcysteine (NAC), diphenyleneiodonium (DPI) were obtained from Sigma Chemical Corp. (St. Louis, $\mathrm{MO}$ ), and FBS from Life Technologies Inc. (Rockville, MD). Monoclonal antibodies against phospho-ERK1/2 (E-4), phospho-JNK (G-7), phospho-p38MapK (D-8), ERK2 (D-2) and polyclonal antibodies against phos-
pho-Akt1 (ser473), PARP (H- 250) were from Santa Cruz Biotechnology (Santa Cruz, CA). Electrophoresis reagents, such as polyacrylamide, Tris-glycine SDS running buffer, and poly (vinylidene difluoride) (PVDF) membrane were from Novex Corp. (San Diego, CA).

\section{Cell culture}

HepG2 cells were obtained from Korean Cell Line Bank (Seoul, Korea) and grown in DMEM containing 100 units $/ \mathrm{ml}$ penicillin, $100 \mu \mathrm{g} / \mathrm{ml}$ streptomycin, and $10 \%$ FBS, and maintained in a humidified atmosphere of $5 \% \mathrm{CO}_{2}$ in air at $37^{\circ} \mathrm{C}$. Two days after plating in 35-mm tissue culture dishes, cells were serum-starved for $24 \mathrm{~h}$ and then treated with different reagents. Cells were quickly frozen in liquid nitrogen and stored at $-70^{\circ} \mathrm{C}$ until analysis.

\section{SDS-PAGE and immunoblotting}

Unless otherwise indicated, cells were lysed in icecold lysis buffer $(50 \mathrm{mM}$ Tris- $\mathrm{HCl}, 1 \%$ nonidet $\mathrm{P}-40$, $0.25 \%$ sodium deoxycholate, $150 \mathrm{mM} \mathrm{NaCl}, 1 \mathrm{mM}$ sodium orthovanadate, $1 \mathrm{mM} \mathrm{NaF}, 1 \mathrm{mM}$ phenylmethylsulfonyl fluoride, $1 \mu \mathrm{M}$ aprotinin, $1 \mu \mathrm{M}$ leupeptin, $1 \mu \mathrm{M}$ pepstatin A). Same amount of proteins were separated by SDS-PAGE on $4-20 \%$ polyacrylamide gel and electrotransferred onto PVDF membrane. The membrane was incubated in blocking buffer $[5 \%$ nonfat dry milk in Tris-buffered saline (TBS)-0.1\% Tween-20 (TBS-T)] for $1 \mathrm{~h}$ at room temperature and then probed with different primary antibodies (1: $1,000-1: 5,000)$. After a series of washes, the membrane was further incubated with different horseradish peroxidase (HRP)-conjugated secondary antibodies $(1: 2,000-1: 10,000)$. The signal was detected with enhanced chemiluminescence (ECL) detection system (Intron, Seoul, Korea).

\section{Determination of caspase-3 activity}

After treatments with reagents, cells were collected and lysed in ice-cold $0.5 \mathrm{ml}$ caspase assay buffer (50 $\mathrm{mM}$ Tris- $\mathrm{HCl}, \mathrm{pH} 7.4,150 \mathrm{mM} \mathrm{NaCl}, 1 \%$ nonidet $\mathrm{P}-40,0.25 \%$ sodium deoxycholate, $1 \mathrm{mM}$ EGTA) for $15 \mathrm{~min}$. After centrifugation at $12,000 \mathrm{~g}$ for $15 \mathrm{~min}$ at $4{ }^{\circ} \mathrm{C}$, aliquots of supernatant were incubated with $10 \mathrm{mM}$ Ac-DEVD-AMC for $3 \mathrm{~h}$ at $37^{\circ} \mathrm{C}$. The fluorescence from the cleaved product was detected with Spectrafluor multiwell fluorescence reader (Tecan, Salzburg, Austria) at $360 \mathrm{~nm}$ and $465 \mathrm{~nm}$ wavelengths for excitation and emission, respectively.

\section{MTT assay}

This measure of mitochondrial function was performed as described previously (Parrizas et al., 1997) with 
cells seeded on 24-well plates. Following treatments, the medium was removed from the wells, and 200 $\mu$ l of MTT reagent (Sigma, St. Louis, MO) at a concentration of $1 \mathrm{mg} / \mathrm{ml}$ in RPMI-1640 medium without phenol red was added to each well. After $1 \mathrm{~h}$ incubation at $37^{\circ} \mathrm{C}$, the cells were lysed by addition of 1 volume of 2-propanol and shaken for $20 \mathrm{~min}$. Absorbance of converted dye was measured at a wavelength of $570-690 \mathrm{~nm}$.

\section{Detection of apoptotic cells with flow cytometric analysis and $\mathrm{H} 33342$ staining}

The degree of apoptosis was determined by measuring the number of cells showing below the G1 DNA content from flow cytometric analysis after staining of cells with propidium iodide as originally described by Crissman and Steinkamp (1993). The samples were analyzed with a Coulter EpicsTM cytometer (Beckman, Fullerton, CA). Ten thousands of events were collected for each sample. An excitation wavelength of $488 \mathrm{~nm}$ and a fluorescence emission of $580 \mathrm{~nm}$ were used. Otherwise, cells were stained with a DNAspecific fluorescent dye (H33342) then observed under a fluorescent microscope equipped with a CoolSNAP-Pro color digital camera (Media Cybernetics, Silver Spring, MD) to examine the degree of nuclear condensation.

\section{Determination of DNA fragmentation}

Cellular DNA was extracted from whole cultured cells using genomic DNA isolation reagents (PureGene DNA isolation kit, Gentra, Minneapolis, MN) by a manufacturer's protocol. Electrophoresis was performed on a $6 \%$ polyacrylamide gel in Tris-borateEDTA (TBE) buffer. After electrophoresis, DNA was visualized by silver staining kit (Intron, Seoul, Korea).

\section{Statistical analysis}

Statistical analysis was performed using an analysis program, StatView ${ }^{R}$ (Abacus Concepts, Berkely, CA). The Student's $t$-test was used to analyze the difference between control and experimental groups. $P<$ 0.05 was considered to be significant.

\section{Results}

\section{Induction of apoptosis by $\mathrm{As}_{2} \mathrm{O}_{3}$}

HepG2 cells were treated with varying concentration of $\mathrm{As}_{2} \mathrm{O}_{3}$ up to $20 \mu \mathrm{M}$ and cellular viability by MTT assay and apoptosis by the degrees of internucleosomal DNA fragmentation and nuclear chromatin condensation were carried out. When confluent cells were incubated for $24 \mathrm{~h}$ in normal culture medium
A

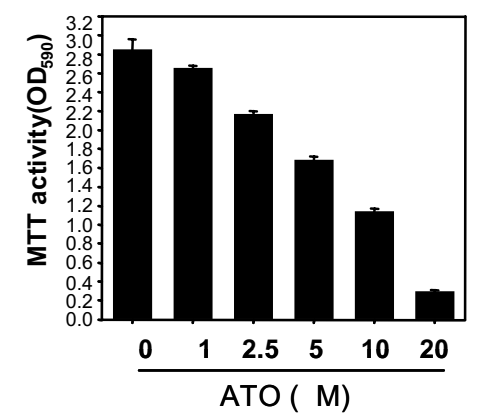

B

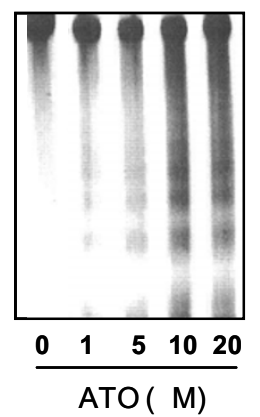

C

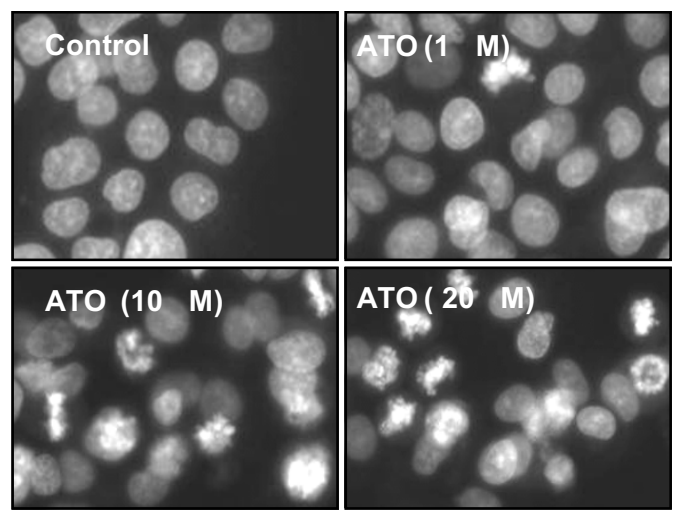

Figure 1. $\mathrm{As}_{2} \mathrm{O}_{3}$ (ATO)-induced apoptosis. HepG2 cells were plated in $35 \mathrm{~mm}$ culture dishes $24 \mathrm{~h}$ before $\mathrm{As}_{2} \mathrm{O}_{3}$ treatment. After replacing with fresh medium containing $10 \% \mathrm{FBS}$, cells were treated with different doses of $\mathrm{As}_{2} \mathrm{O}_{3}$ as indicated for an additional $24 \mathrm{~h}$. Viability of each group was assessed by a MTT assay. Each bar represents the mean $\pm S E$ of three independent experiments $(n=3)(A)$. A representative of internucleosomal DNA fragmentation is shown in (B). Cellular DNA was isolated, separated on a $6 \%$ polyacrylamide gel and visualized with silver staining. $\mathrm{H} 33342(10 \mu \mathrm{g} / \mathrm{ml})$ was added directly into the cultured cells after $\mathrm{As}_{2} \mathrm{O}_{3}$ treatment for $24 \mathrm{~h}$ and maintained for $20 \mathrm{~min}$. The fluorescent images were captured with the inverted fluorescent microscope at $200 x$ magnification (C).

containing $\mathrm{As}_{2} \mathrm{O}_{3}(1-20 \mu \mathrm{M})$, MTT activity was linearly declined in a dose-dependent manner (Figure 1A). However, at low concentrations of $\mathrm{As}_{2} \mathrm{O}_{3}$ less than 2 $\mu \mathrm{M}$, MTT activity was still comparable to that of control group. The degree of DNA fragmentation or nuclear condensation was not affected by treatments with low concentrations of $\mathrm{As}_{2} \mathrm{O}_{3}$ (Figure $1 \mathrm{~B}$ and $\mathrm{C}$ ). However, higher concentrations of $\mathrm{As}_{2} \mathrm{O}_{3}$ greater than $10 \mu \mathrm{M}$ sharply decreased MTT activity and induced DNA fragmentation and nuclear condensation. Interestingly, the number of cells with chromosomes at mitotic metaphase as well as cells with condensedor blebbed nuclei was increased at $24 \mathrm{~h}$ after 10-20 $\mu \mathrm{M} \mathrm{As} \mathrm{O}_{2}$ treatment (Figure $1 \mathrm{C}$ ). Results from cell cycle analysis also showed an increase of the number of cells at metaphase as well as that of apoptotic 


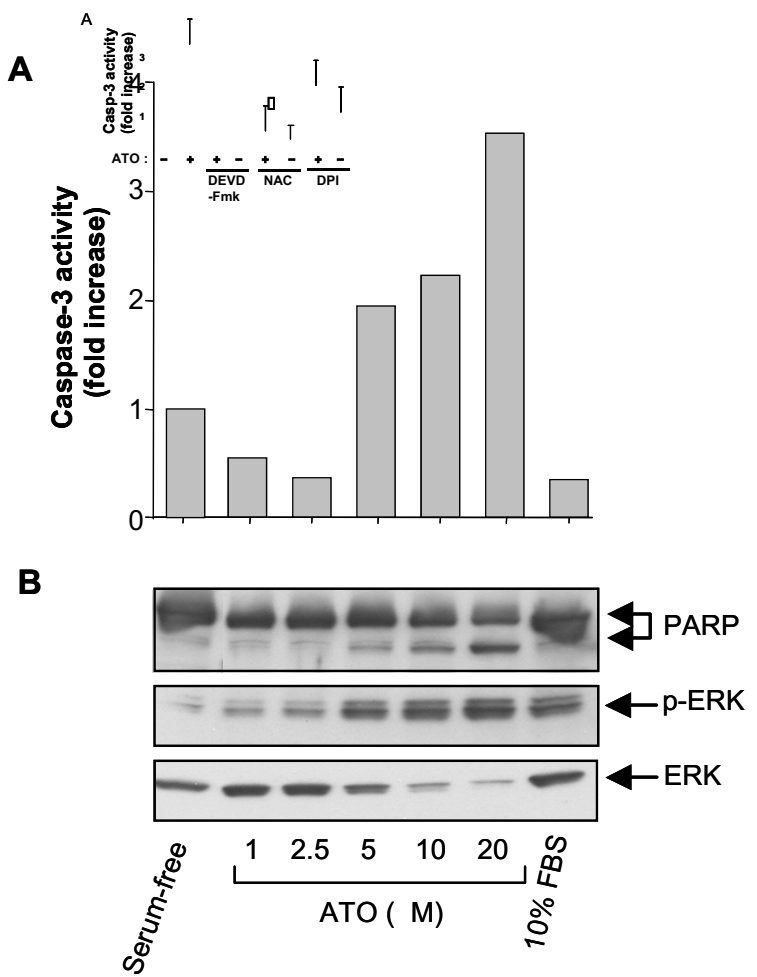

Figure 2. $\mathrm{As}_{2} \mathrm{O}_{3}$ induces caspase-3 stimulation and PARP hydrolysis. HepG2 cells in $35 \mathrm{~mm}$ dishes were serum-starved for $24 \mathrm{~h}$ before treatment and replaced with fresh serum-free medium containing different doses of $\mathrm{As}_{2} \mathrm{O}_{3}$ or normal culture medium containing $10 \%$ FBS. (A) After an additional incubation for $24 \mathrm{~h}$, cells were homogenized in $200 \mu \mathrm{l}$ lysis buffer without protease inhibitors and aliquots of supernatant were incubated with Ac-DEVD-AMC $(10 \mu \mathrm{M})$ for $3 \mathrm{~h}$ at $37^{\circ} \mathrm{C}$. Caspase- 3 activities were presented as fold increases over control (serum-free). Each bar represents a mean of two independent experiments. (B) After treatments, cells were lysed in ice-cold lysis buffer $(200 \mu \mathrm{I})$. Same amounts of proteins were separated by SDSPAGE on $4-20 \%$ polyacrylamide gel and subjected to immunoblot analysis using an antibody to PARP $(1: 1,000)$ as described in Materials and Methods. Blots were repeatedly stripped and reprobed with different antibodies to phospho-ERK (P-ERK), and ERK as an internal standard. The panel is a representative of two separate experiments.

cells at $24 \mathrm{~h}$ after $10-20 \mu \mathrm{M} \mathrm{As} \mathrm{O}_{3}$ treatment, however, most of cells became apoptotic after $48 \mathrm{~h}$ incubation (data not shown).

Caspase- 3 activity and the degree of hydrolysis of poly (ADP-ribose) polymerase (PARP), common indicators of the occurrence of apoptosis measurement showed a small occurrence of cell apoptosis at concentrations less than $2 \mu \mathrm{M} \mathrm{As} \mathrm{O}_{3}$ (Figure 1) whereas caspase- 3 activity and the degree of PARP hydrolysis were markedly elevated at higher concentrations of $\mathrm{As}_{2} \mathrm{O}_{3}$ after $24 \mathrm{~h}$ treatment of cells (Figure 2). Interestingly, HepG2 cells were found to be less apoptotic in serum-free conditions for $24 \mathrm{~h}$ indicated by a weak caspase- 3 activation or the absence of PARP hydrolysis.

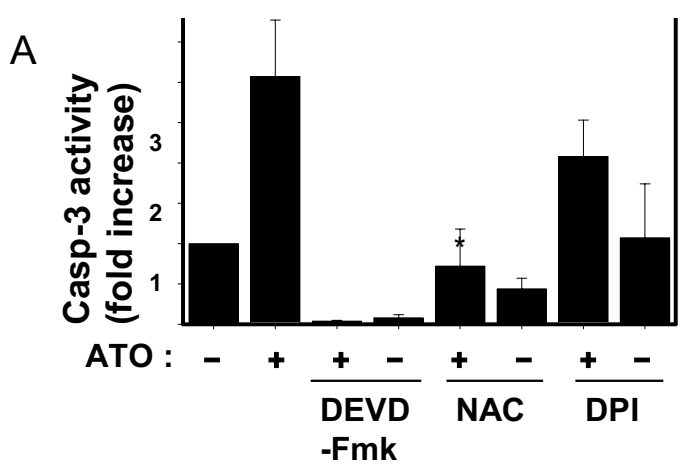

B

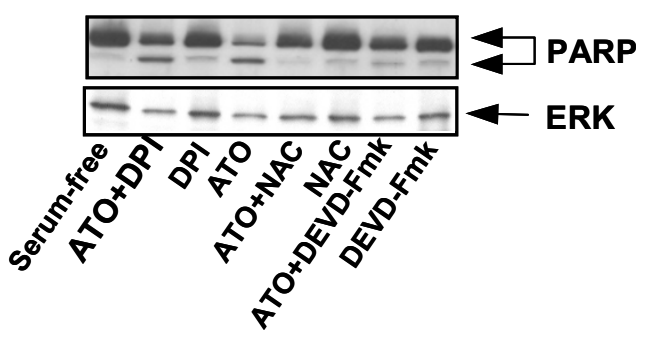

C

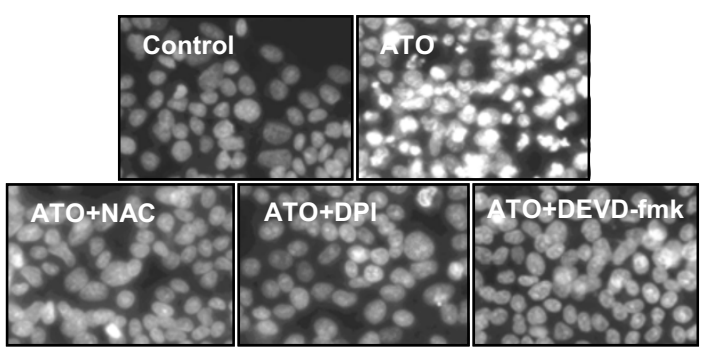

Figure 3. Antioxidants suppress caspase-3 stimulation, PARP hydrolysis and nuclear condensation. Serum-starved $(24 \mathrm{~h})$ cells were pretreated with $10 \mu \mathrm{M}$ z-DEVD-fmk, $2 \mathrm{mM} \mathrm{NAC}$ or $1 \mu \mathrm{M} \mathrm{DPI}$ for $30 \mathrm{~min}$ and further incubated for $24 \mathrm{~h}$ in the absence or presence of $10 \mu \mathrm{M} \mathrm{As} \mathrm{O}_{3}$. (A) Caspase-3 activity was assayed as described in Figure 2. Each bar represents the mean $\pm S E$ of three independent experiments $(n=3)$. ${ }^{*} P<0.05$ compared to the control $\left(\mathrm{As}_{2} \mathrm{O}_{3}\right.$-alone). Immunoblotting for PARP and ERK (B) and observation of nuclear condensation (C) were performed using cells treated for $24 \mathrm{~h}$. Note that HepG2 cells are less apoptotic even incubated in the serum-free medium shown in $(A)-(C)$. Each panel $(B)$ or $(C)$ is a representative of three independent experiments.

\section{Effects of antioxidants on the apoptotic activity of $\mathrm{As}_{2} \mathrm{O}_{3}$}

The roles of reactive oxygen species (ROS) in $\mathrm{As}_{2} \mathrm{O}_{3}$ induced apoptosis are well documented. The study was carried to examine the effects of known antioxidants, NAC, an effective scavenger molecule of intracellular ROS and DPI, a reagent widely used to inhibit iNOS on the $\mathrm{As}_{2} \mathrm{O}_{3}$-treated cells. NAC completely protected cells treated with $10 \mu \mathrm{M} \mathrm{As}{ }_{2} \mathrm{O}_{3}$ from apoptosis, suppressed caspase- 3 stimulation, and 
PARP hydrolysis induced by (Figure 3), suggesting the mediation of $\mathrm{As}_{2} \mathrm{O}_{3}$-induced apoptosis by $\mathrm{ROS}$ and caspase cascades. Caspase- 3 stimulation or PARP hydrolysis in the cells treated by $\mathrm{As}_{2} \mathrm{O}_{3}$ was not significantly suppressed by the addition of DPI whereas nuclear condensation was suppressed. DPI is known to irreversibly inhibit not only iNOS in macrophages but also endothelial NOS (eNOS) (Stuehr and Griffith, 1992). Moreover, DPI is also known to inhibit mitochondrial NADPH oxido-reductase (Majander et al., 1994). A specific inhibitors against iNOS was selected to examine possible dependence of iNOS stimulation in $\mathrm{As}_{2} \mathrm{O}_{3}$ induced apoptosis. GED and ETU are highly specific and potent inhibitors of iNOS over both eNOS or neuronal NOS (nNOS). Inhibition of iNOS by GED and ETU effectively suppressed PARP hydrolysis and nuclear condensation in cells treated with $\mathrm{As}_{2} \mathrm{O}_{3}$ (Figure 4). Again, serum-free condition did not affect cell's viability at least within 24 $\mathrm{h}$, like as shown in Figure 2 and 3.

A

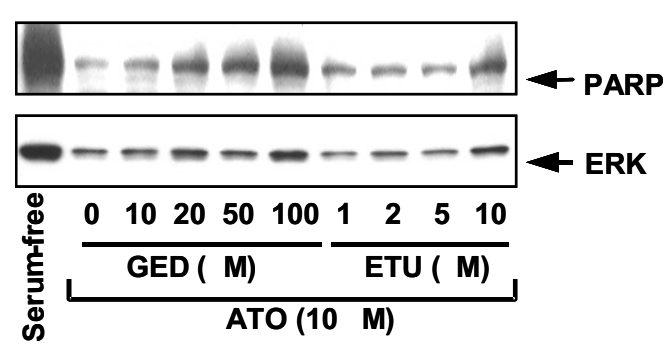

B

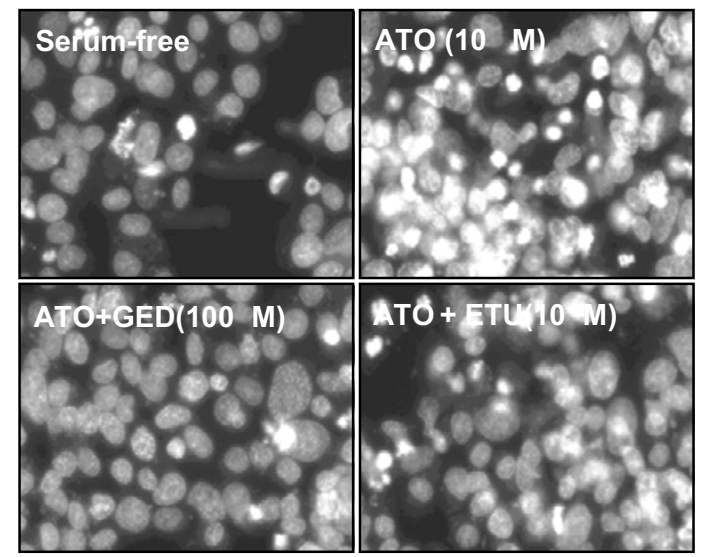

Figure 4. Inhibition of iNOS can protect HepG2 cells from apoptosis induced by $\mathrm{As}_{2} \mathrm{O}_{3}$. Serum-starved $(24 \mathrm{~h})$ cells were pretreated with different doses of GED $(0-100 \mu \mathrm{M})$ or ETU $(0-10 \mu \mathrm{M})$ for $30 \mathrm{~min}$ and further incubated for $24 \mathrm{~h}$ in the absence or presence of $10 \mu \mathrm{M}$ $\mathrm{As}_{2} \mathrm{O}_{3}$. Immunoblotting for PARP and ERK (A) and observation of nuclear condensation (B) were performed as described in the previous experimets. Note that HepG2 cells are less apoptotic even incubated in the serum-free medium. Each panel is a representative of three independent experiments.

\section{Roles of stress-responsive signaling proteins in $\mathrm{As}_{2} \mathrm{O}_{3}$-induced apoptosis}

Members of MAPK families including ERK, JNK and p38 are activated in response to stimuli by growth factors as well as extracellular stresses. Stimulations of MAPKs are generally known to promote cell proliferation, but occasionally lead to apoptosis of severely effected cells by a number of physical and chemical stresses (Barchowsky et al., 1999; Bernstam and Nriagu, 2000). Here we examined whether $\mathrm{As}_{2} \mathrm{O}_{3}$ can stimulate activities of members of MAPK family. When cells were treated with $10 \mu \mathrm{M} \mathrm{As} \mathrm{O}_{3}$ for $60 \mathrm{~min}$, remarkable stimulations of JNK and ERK but not p38 were observed from immunoblots using phosphospecific antibodies against signaling proteins (Figure 5A). PD98059, an inhibitor of MEK, completely blocked ERK stimulation by $\mathrm{As}_{2} \mathrm{O}_{3}$ but failed to inhibit proteolytic cleavage of procaspase-3 to be activated (Figure 5B). Protein contents of intact ERK, JNK or p38 were not changed in any groups (only ERK-panel was shown in Figure 5). Failure of PD98059 to block $\mathrm{As}_{2} \mathrm{O}_{3}$-induced apoptosis also demonstrated in separate experiments measuring intracellular DNA content by flow cytometric analysis (Figure $6 \mathrm{~A}$ ) and the degree of nuclear condensation (Figure 6B). These results suggest that $\mathrm{As}_{2} \mathrm{O}_{3}$-induced $\mathrm{ERK}$ activation is not crucial, at least, in the course of caspase-3-

A

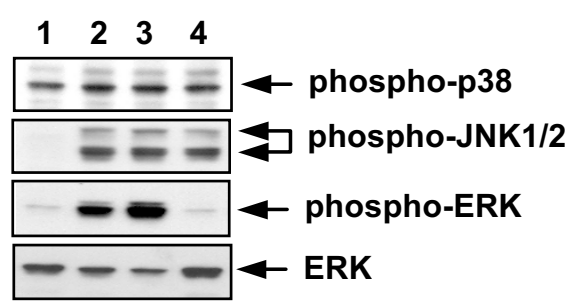

B

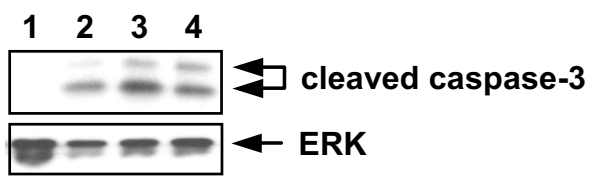
1. Control (serum-free)
2. ATO $(20 \mu \mathrm{M})$
3. $\quad$ ATO + SB202190 $(10 \mu \mathrm{M})$
4. $\quad$ ATO + PD98059 $(50 \mu M)$

Figure 5. $\mathrm{As}_{2} \mathrm{O}_{3}$ stimulates ERK and JNK but not p38 MAPK and inhibition of ERK does not suppress PARP hydrolysis induced by $\mathrm{As}_{2} \mathrm{O}_{3}$. Serum-starved $(24 \mathrm{~h})$ cells were pretreated with inhibitors against ERK (PD98059, $50 \mu \mathrm{M})$ or p38 MAPK (SB202190, $10 \mu \mathrm{M}$ ) for $30 \mathrm{~min}$ and further incubated for $60 \mathrm{~min}$ for the detection of activities of p38 MAPK, ERK and JNK (A), or for $24 \mathrm{~h}$ for the detection of cleavage of inactive procaspase- 3 into active caspase- $3(B)$ in the absence or presence of $10 \mu \mathrm{M} \mathrm{As} \mathrm{O}_{3}$. Each panel is a representative of three independent experiments. 
A
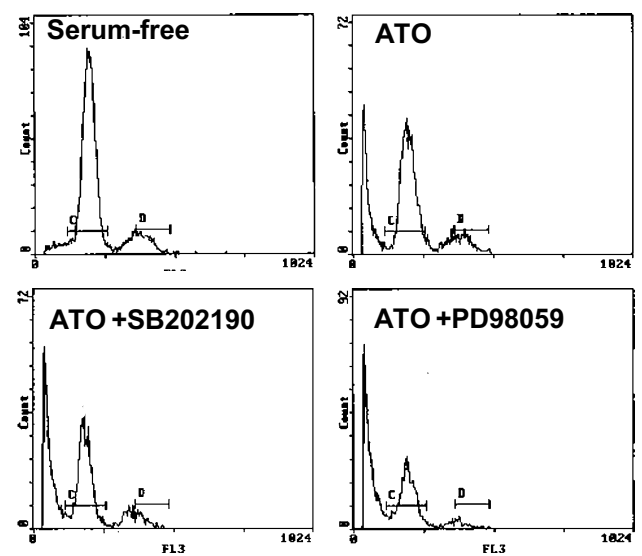

B

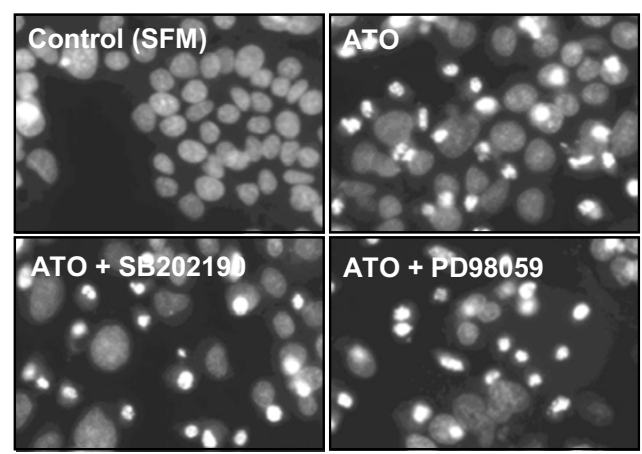

Figure 6. Inhibition of $\mathrm{As}_{2} \mathrm{O}_{3}$-induced ERK stimulation cannot protect cells from apoptosis. Serum-starved $(24 \mathrm{~h})$ cells were pretreated with inhibitors against ERK (PD98059, $50 \mu \mathrm{M}$ ) or p38 MAPK (SB202190, 10 $\mu \mathrm{M})$ for $30 \mathrm{~min}$ and further incubated for $24 \mathrm{~h}$. Cells were trypsinized, fixed and stained with propidium iodide $(10 \mu \mathrm{g} / \mathrm{ml}$ in PBS) for the flow cytometric analysis. Population of apoptotic cells is represented as the first peak (sub G1) in each panel (A). Observation of nuclear condensation (B) was performed as described before. Note that HepG2 cells are less apoptotic even incubated in the serum-free medium. Each panel is a representative of three independent experiments.

mediated apoptotic processes by $\mathrm{As}_{2} \mathrm{O}_{3}$. The importance of JNK stimulation in $\mathrm{As}_{2} \mathrm{O}_{3}$-induced apoptosis was not clear at present due to the limited availability of inhibitors against JNK. As shown in Figure 3C, antioxidants like as NAC and DPI suppressed apoptosis in the $\mathrm{As}_{2} \mathrm{O}_{3}$ treated cells. Experiment was carried out to examine the effect on MAPK proteins in the cells treated with different antioxidants together with $\mathrm{As}_{2} \mathrm{O}_{3}$. As shown in Figure 7, treatments of cells with antioxidants; NAC, DPI or even PDTC (1-pyrrolidinecarbodithioic acid, an inhibitor of superoxide dismutase) did not suppress activities of ERK or JNK stimulated by $\mathrm{As}_{2} \mathrm{O}_{3}$. Thus, activations of JNK as well as ERK by $\mathrm{As}_{2} \mathrm{O}_{3}$ do not seem to play crucial roles to lead HepG2 cells to apoptosis.

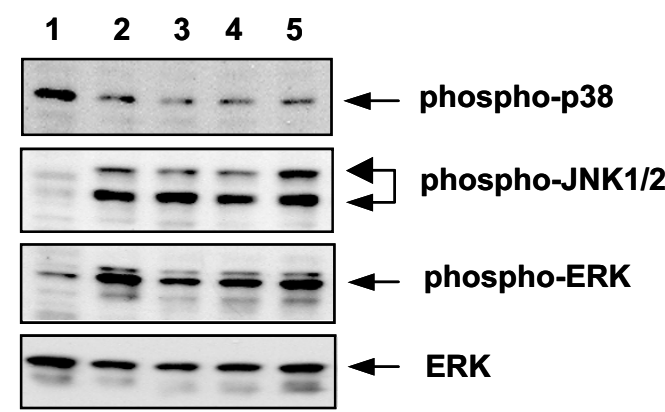

Figure 7. Antioxidants do not inhibit ERK- or JNK-stimulation by $\mathrm{As}_{2} \mathrm{O}_{3}$. Serum-starved $(24 \mathrm{~h})$ cells were pretreated with $2 \mathrm{mM} \mathrm{NAC}$, $1 \mu \mathrm{M}$ DPI or $1 \mathrm{mM}$ PDTC for $30 \mathrm{~min}$ and further incubated for 60 min in the absence or presence of $10 \mu \mathrm{M} \mathrm{As}_{2} \mathrm{O}_{3}$. Immunoblotting for the detection of activated p38 Map kinase, ERK, JNK or ERK (internal standard) were performed as described in previous experiments. Lanes: 1, control (serum-free); 2, ATO $(10 \mu \mathrm{M}) ; 3$, ATO+DPI $(1 \mu \mathrm{M})$; 4, ATO+ NAC (1 mM); 5, ATO+PDTC (1 mM). The panel is a representative of three independent experiments.

\section{Discussion}

Although $\mathrm{As}_{2} \mathrm{O}_{3}$ has been successful in inducing apoptosis in APL and other leukemic cancer cells, there is little evidence against solid tumor cells. The present study showed an effectiveness of $\mathrm{As}_{2} \mathrm{O}_{3}$ to lead HepG2 cells into apoptosis at concentrations higher than $10 \mu \mathrm{M}$. These results imply that HepG2 cells are more resistant to $\mathrm{As}_{2} \mathrm{O}_{3}$ in comparison with APL cells and other leukemic cancer cells sensitive to lower concentrations $(<5 \mu \mathrm{M}$ ) (Akao et al., 1999; Gurr et al., 1999). Interestingly, HepG2 cells incubated in serum-free medium for $24 \mathrm{~h}$ were not respondent to $\mathrm{As}_{2} \mathrm{O}_{3}$. These results show a remarkable survival potential of HepG2 cells even in nutrientdeficient conditions because most of immortalized cell lines are apoptotic in serum-free conditions at least within $24 \mathrm{~h}$. In addition, a delayed onset of apoptosis after accumulations of cells at mitotic metaphase was observed for $48 \mathrm{~h}$ treatment with $\mathrm{As}_{2} \mathrm{O}_{3}$. Recently, $\mathrm{As}_{2} \mathrm{O}_{3}(0.5-6 \mu \mathrm{M})$ was shown to induce $\mathrm{G} 2 / \mathrm{M}$ growth arrest which was associated with changes in the amount of cyclin B and cyclin B-dependent kinase and apoptosis in promonocytic U937 cells after $24 \mathrm{~h}$ treatment (Park et al., 2001), suggesting $\mathrm{As}_{2} \mathrm{O}_{3}$ 's growth-inhibitory effects by modulating expressions and/or activities of several key G2/M regulatory proteins. However, in MC/CAR myeloma cells, $\mathrm{As}_{2} \mathrm{O}_{3}$ induced $\mathrm{G} 1$ arrest as well as $\mathrm{G} 2 / \mathrm{M}$ arrest, binding Cip/p21 to cyclin E and cyclin A, but did not change the steady-state levels of cyclin B1, cyclin E and cyclin D1 (Park et al., 2000). In head and neck cancer cell line $\mathrm{PCl}-1, \mathrm{As}_{2} \mathrm{O}_{3}$ induced $\mathrm{G} 2 / \mathrm{M}$ arrest whereas it did not change the steady-state levels of 
cyclin D1, cyclin $E$ and cyclin $A$ but decreased protein levels of cyclin B1 (Seol et al., 1999). Therefore, $\mathrm{As}_{2} \mathrm{O}_{3}$-induced cell cycle arrest might be associated with different changes in the amount and activity of even a same cell cycle-modulating protein in different cell models. The present study did not measure expression levels or activities of $\mathrm{G} 2 / \mathrm{M}$ regulatory proteins after $\mathrm{As}_{2} \mathrm{O}_{3}$ treatment in HepG2 cells. However, our results provide an evidence to support a hypothesis that $\mathrm{As}_{2} \mathrm{O}_{3}$ leads to cell cycle arrest at $\mathrm{G} 2 / \mathrm{M}$ phase and subsequent onset of apoptosis. Stimuations of caspase- 3 and hydrolysis of poly (ADP-ribose) polymerase (PARP) by $\mathrm{As}_{2} \mathrm{O}_{3}$ (10-20 $\mu \mathrm{M})$ support the notion that $\mathrm{As}_{2} \mathrm{O}_{3}$ leads $\mathrm{HepG} 2$ cell to apoptosis by inducing typical, stepwise stimulations of apoptotic biochemical changes. These results are paralleled with other studies showing the classic morphologic and biochemical changes of apoptosis induced by $\mathrm{As}_{2} \mathrm{O}_{3}$.

Recently, the role of reactive oxygen species (ROS) in $\mathrm{As}_{2} \mathrm{O}_{3}$-induced apoptosis was extensively studied. $\mathrm{As}_{2} \mathrm{O}_{3}$ inhibits glutathione peroxidase (GPx) activity and increases cellular hydrogen peroxide $\left(\mathrm{H}_{2} \mathrm{O}_{2}\right)$ content in NB4 but not U937 cells, thereby induces cytochromc c release, caspase- 3 activation and DNA fragmentation (Jing et al., 1999). Our data suggests the mediating role of ROS in the course of $\mathrm{As}_{2} \mathrm{O}_{3}$ induced apoptosis. Other studies also have reported similar results regarding the involvement of ROS in $\mathrm{As}_{2} \mathrm{O}_{3}$-induced apoptosis in different cellular models (Barchowsky et al., 1999; Akao et al., 2000). From these results, the mediating role of ROS in inducing apoptosis by $\mathrm{As}_{2} \mathrm{O}_{3}$ in HepG2 cells should also be considered.

The involvement of members of MAPK families in $\mathrm{As}_{2} \mathrm{O}_{3}$-induced apoptosis is still controversial. Barchowsky et al. (1999) observed activations of ERK and p38 in arsenite-induced apoptosis in primary vascular cells. Oxidative stress by arsenic compounds induced stimulations of ERK, JNK and p38 MAPK activities in different cell models (Bernstam and Nriagu, 2000). In the meanwhile, Maeda et al. (2001) showed activations of JNK and p38 after $\mathrm{As}_{2} \mathrm{O}_{3}$ treatment in prostate cancer cells, however, pharmacological inhibition of p38 and over-expression of dominant-negative JNK failed to protect cells from apoptosis by $\mathrm{As}_{2} \mathrm{O}_{3}$. In the meanwhile, $\mathrm{As}_{2} \mathrm{O}_{3}$ leads to inactivation of ERK, and activation of p38 that plays a role in inducing apoptosis by $\mathrm{As}_{2} \mathrm{O}_{3}$ in human leukemia U937 cells (Iwama et al., 2001). These diverse observations about signaling nature in $\mathrm{As}_{2} \mathrm{O}_{3}$ induced apoptosis represent the unusual characteristics of the mechanism of apoptosis by $\mathrm{As}_{2} \mathrm{O}_{3}$ in different cellular systems.

In summary, moderately higher concentrations of $\mathrm{As}_{2} \mathrm{O}_{3}$ (not less than $2 \mu \mathrm{M}$ ) induce apoptosis and antioxidants can protect cells from apoptosis by $\mathrm{As}_{2} \mathrm{O}_{3}$ in HepG2 cells. Although ERK and JNK, not p38 are stimulated in response to $\mathrm{As}_{2} \mathrm{O}_{3}$, they might not play important roles in executing proapoptotic activity of $\mathrm{As}_{2} \mathrm{O}_{3}$. In addition, inhibition of iNOS can protect HepG2 cells from apoptosis induced by $\mathrm{As}_{2} \mathrm{O}_{3}$, suggesting the stimulation of ROS production by $\mathrm{As}_{2} \mathrm{O}_{3}$ as one of its apoptotic processes.

\section{Acknowledgement}

This work was supported by a grant from the Cheju National University Medical Research Fund (2000).

\section{References}

Akao Y, Mizoguchi H, Kojima S, Naoe T, Ohishi N, Yagi $\mathrm{K}$. Arsenic induces apoptosis in B-cell leukaemic cell lines in vitro: activation of caspases and down-regulation of $\mathrm{Bcl}-2$ protein. $\mathrm{Br} \mathrm{J}$ Haematol 1998;2:1055-60

Akao $Y$, Nakagawa $Y$, Akiyama K. Arsenic trioxide induces apoptosis in neuroblastoma cell lines through the activation of caspase 3 in vitro. FEBS Lett 1999;455:59-62

Akao Y, Yamada H, Nakagawa Y. Arsenic-induced apoptosis in malignant cells in vitro. Leuk Lymphoma 2000;37:53-63

Barchowsky A, Klei LR, Dudek EJ, Swartz HM, James PE. Stimulation of reactive oxygen, but not reactive nitrogen species, in vascular endothelial cells exposed to low levels of arsenite. Free Radic Biol Med 1999;27:1405-126

Barchowsky A, Roussel RR, Klei LR, James PE, Ganju N, Smith KR, Dudek EJ. Low levels of arsenic trioxide stimulate proliferative signals in primary vascular cells without activating stress effector pathways. Toxicol Appl Pharmacol 1999;159:65-75

Bernstam L, Nriagu J. Molecular aspects of arsenic stress. J Toxicol Environ Health B Crit Rev 2000;3:293-322

Cavigelli M, Li WW, Lin A, Su B, Yoshioka K, Karin M. The tumor promoter arsenite stimulates AP-1 activity by inhibiting a JNK phosphatase. EMBO J 1996;15:6269-79

Crissman HA, Steinkamp JA. Cell cycle-related changes in chromatin structure detected by flow cytometry using multiple DNA fluorochromes. Eur J Histochem 1993;37:129-38

Gurr JR, Bau DT, Liu F, Lynn S, Jan KY. Dithiothreitol enhances arsenic trioxide-induced apoptosis in NB4 cells. Mol Pharmacol 1999;56:102-9

Huang SL, Guo AX, Xiang Y. Clinical study on the treatment of APL mainly with composite Indigo Naturalis tablets. Chin J Hematol 1995;16:26-29

Ishitsuka K, Hanada S, Uozumi K, Utsunomiya A, Arima T. Arsenic trioxide and the growth of human $t$-cell leukemia virus type i infected t-cell lines. Leuk Lymphoma 2000; 37:649-55

Iwama K, Nakajo S, Aiuchi T, Nakaya K. Apoptosis induced by arsenic trioxide in leukemia U937 cells is dependent on activation of $\mathrm{p} 38$, inactivation of ERK and the $\mathrm{Ca}^{2+}$-depen- 
dent production of superoxide. Int J Cancer 2001;92:518-26

Jiang $\mathrm{XH}$, Wong $\mathrm{BC}$, Yuen ST, Jiang $\mathrm{SH}$, Cho $\mathrm{CH}$, Lai $\mathrm{KC}$, Lin MC, Kung HF, Lam SK, Chun-Y, Wong B. Arsenic trioxide induces apoptosis in human gastric cancer cells through up-regulation of p53 and activation of caspase-3. Int J Cancer 2001;91:173-9

Jing Y, Dai J, Chalmers-Redman RM, Tatton WG, Waxman $\mathrm{S}$. Arsenic trioxide selectively induces acute promyelocytic leukemia cell apoptosis via a hydrogen peroxide-dependent pathway. Blood 1999;94:2102-114

Maeda H, Hori S, Nishitoh H, Ichijo H, Ogawa O, Kakehi $\mathrm{Y}$, Kakizuka A. Tumor growth inhibition by arsenic trioxide $\left(\mathrm{As}_{2} \mathrm{O}_{3}\right)$ in the orthotopic metastasis model of androgenindependent prostate cancer. Cancer Res 2001;61:5432-40

Majander A, Finel M, Wikstrom M. Diphenyleneiodonium inhibits reduction of iron-sulfur clusters in the mitochondrial NADH-ubiquinone oxidoreductase (Complex I). J Biol Chem 1994;269:21037-42

Miller WH Jr, Schipper HM, Lee JS, Singer J, Waxman S. Mechanisms of action of arsenic trioxide. Cancer Res 2002; 62:3893-903

Park JW, Choi YJ, Jang MA, Baek SH, Lim JH, Passaniti T, Kwon TK. Arsenic trioxide induces G2/M growth arrest and apoptosis after caspase-3 activation and bcl-2 phosphorylation in promonocytic U937 cells. Biochem Biophys Res Commun 2001;286:726-34

Park WH, Seol JG, Kim ES, Hyun JM, Jung CW, Lee CC, Kim BK, Lee YY. Arsenic trioxide-mediated growth inhibition in MC/CAR myeloma cells via cell cycle arrest in association with induction of cyclin-dependent kinase inhibitor, p21, and apoptosis. Cancer Res 2000;60:3065-71

Parrizas M, Saltiel AR, LeRoith D. Insulin-like growth factor 1 inhibits apoptosis using the phosphatidylinositol 3'-kinase and mitogen-activated protein kinase pathways. J Biol Chem 1997;272:154-61

Porter AC, Fanger GR, Vaillancourt RR. Signal transduction pathways regulated by arsenate and arsenite. Oncogene 1999;18:7794-802

Seol JG, Park WH, Kim ES, Jung CW, Hyun JM, Kim BK, Lee YY. Effect of arsenic trioxide on cell cycle arrest in head and neck cancer cell line PCl-1. Biochem Biophys Res Commun 1999;265:400-4

Shen L, Chen TX, Wang YP, Lin Z, Zhao HJ, Zu YZ, Wu $\mathrm{G}$, Ying DM. $\mathrm{As}_{2} \mathrm{O}_{3}$ induces apoptosis of the human $\mathrm{B}$ lymphoma cell line MBC-1. J Biol Regul Homeost Agents 2000;14:116-9

Shen ZX, Chen GQ, Ni JH, Li XS, Xiong SM, Qiu QY, Zhu $J$, Tang $W$, Sun $G L$, Yang $K Q$, Chen $Y$, Zhou L, Fang ZW, Wang YT, Ma J, Zhang P, Zhang TD, Chen SJ, Chen Z, Wang ZY. Use of arsenic trioxide $\left(\mathrm{As}_{2} \mathrm{O}_{3}\right)$ in the treatment of acute promyelocytic leukemia (APL): II. Clinical efficacy and pharmacokinetics in relapsed patients. Blood 1997;89: 3354-60

Simeonova PP, Luster MI. Mechanisms of arsenic carcinogenicity: genetic or epigenetic mechanisms? J Environ Pathol Toxicol Oncol 2000;19:281-6

Snow ET. Metal carcinogenesis: Mechanistic implications. Pharmacol Ther 1992;53:31-65

Soignet SL, Maslak P, Wang ZG, Jhanwar S, Calleja E, Dardashti LJ, Corso D, DeBlasio A, Gabrilove J, Scheinberg DA, Pandolfi PP, Warrell RP Jr. Complete remission after treatment of acute promyelocytic leukemia with arsenic trioxide. N Engl J Med 1998;339:1341-8

Stuehr DJ, Griffith OW. Mammalian nitric oxide synthases. Adv Enzymol Relat Areas Mol Biol 1992;65:287-34

Thomas X, Dombret H, Cordonnier C, Pigneux A, Gardin C, Guerci A, Vekhoff A, Sadoun A, Stamatoullas A, Fegueux N, Maloisel F, Cahn JY, Reman O, Gratecos N, Berthou C, Huguet $F$, Kotoucek $P$, Travade $P$, Buzyn A, de Revel T, Vilque JP, Naccache P, Chomienne C, Degos L, Fenaux P. Treatment of relapsing acute promyelocytic leukemia by all-trans retinoic acid therapy followed by timed sequential chemotherapy and stem cell transplantation. APL Study Group. Acute promyelocytic leukemia. Leukemia 2000;14: 1006-134

Wang ZG, Rivi R, Delva L, Konig A, Scheinberg DA, Gambacorti-Passerini C, Gabrilove JL, Warrell RP Jr, Pandolfi PP. Arsenic trioxide and melarsoprol induce programmed cell death in myeloid leukemia cell lines and function in a PML and PML-RARalpha independent manner. Blood 1998;92: 1497-50

Wu W, Graves LM, Jaspers I, Devlin RB, Reed W, Samet JM. Activation of the EGF receptor signaling pathway in human airway epithelial cells exposed to metals. Am J Physiol 1999;277:L924-31

Yih LH, Lee TC. Arsenite induces p53 accumulation through an ATM-dependent pathway in human fibroblasts. Cancer Res 2000;60:6346-52 